\title{
Analysis of secularization in Brazil ${ }^{\star}$
}

\author{
Caroline Carvalho* \\ Guilherme Irffi ${ }^{\star \star \star}$
}

This paper analyzes whether Brazil is experiencing a religious secularization process using data from Brazil Religion Survey conducted in 2007. Models of discrete choice are estimated to understand which individual attributes affect disaffiliation, disbelief and lack of religious practice, therefore confirming or disproving secularism hypotheses. Estimations confirm some hypotheses of the theory, for example, that having liberal opinions concerning moral and social issues is positively associated with secularism, and that lower income levels result in lower chances of disaffiliation. In addition, the profile of non-religious people, non-believers and those who do not practice religion is similar. Therefore, it is possible to affirm that there is secularization in Brazil.

Keywords: Secularization. Brazil. Models of discrete choice.

\footnotetext{
* The authors wish to thank Daniel Suliano, Mércia Santos da Cruz, and Ricardo Brito, as well as the participants of the XX Encontro Regional de Economia and the $43^{\circ}$ Encontro Nacional de Economia for their comments. The authors retain sole responsibility for any errors or omissions.

Guilherme Irffi is grateful to the Conselho Nacional de Desenvolvimento Científico e Tecnológico (CNPq) for their financial support.

** Programa de Pós-Graduação em Economia da Universidade Federal do Ceará (Caen/UFC), Fortaleza-CE, Brazil (carolinnedepaula@hotmail.com; https://orcid.org/0000-0002-1032-2260).

*** Departamento de Economia Aplicada e Programa de Pós-Graduação em Economia da Universidade Federal do Ceará (Caen/UFC), Fortaleza-CE, Brazil (guidirffi@gmail.com; https://orcid.org/0000-0002-3558-7628).
} 


\section{Introduction}

In 2010, according to a study by Hackett and Grim (2012), 1.1 billion people around the world had no religious affiliation. In the same year, non-religious people accounted for $20 \%$ of the United States population and $25 \%$ in the United Kingdom. According to the Brazilian Demographic Census of 2010, Brazil seems to follow this worldwide trend, since about $8 \%$ of the population in the country does not belong to any religion.

The number of those without religion grew sharply in the past four decades, since in 1980 only $1.9 \%$ of Brazilians declared themselves as non-religious (COUTINHO; GOLGHER, 2014). As these numbers increased in recent years in an accelerated manner, the cause is unlikely to be the simple vegetative growth of non-religious people, but the movement of people who belonged to a religion and have decided to abandon it.

The abandonment of religion (apostasy) can be seen as a particular case of religious transit, and this is justified by the dissatisfaction of the faithful with a religious institution to which they belong (IANNACCONE, 1998). In fact, those who have no religion have extensive religious wanderings (RODRIGUES, 2007). The Brazilian religious pluralism would thus be the consequence of a historic process of controversies about healing practices, witchcraft and possession which culminated in the "invention" of new religions; and also of the Catholic religion operating as model and reference for the formulation of rights and framework of popular practices as religious (MONTERO, 2009).

Apostasy may reflect disenchantment with religions in general, which does not necessarily imply atheism, but a weakening of traditional beliefs. Among those with religious affiliation, the absence of commitment to religion via religious practice and beliefs can weaken the bond with it (HALMAN; DRAULANS, 2006). A sign of this is the indifference to doctrines related to issues such as abortion, homosexual union, etc. The literature refers to the process by which religion loses its importance as secularization.

The goal of this study is to analyze whether the phenomenon of secularization is present in Brazilian society. To that end, we have used the theoretical framework proposed by Azzi and Ehrenberg (1975), which is a utility model which considers that individuals allocate time between religious and secular activities. Secular behavior is observed through three distinct manifestations: disaffiliation; disbelief; and lack of religious practice.

Religious disaffiliation aims to compare individuals who have always belonged to a religion to those who have a religion and, at some point, decide to abandon it, and reported having no religious affiliation at the time of the survey. To capture disbelief, questions concerning beliefs about the existence of God and that after death some people go to Heaven or Hell are used. Finally, the absence of religious practice is measured in the absence of worship, church or religious services, and in lack of prayers.

From the estimation of models of discrete choice, we expected to confirm the hypothesis of secularization theory for the profile of disaffiliation, non-believers and non - practicing. We expected to find no correspondence between belonging to a religion and beliefs or practices 
required by it. This paper also investigates which demographic, socioeconomic, cultural and geographical attributes of the population are related to the decision of abandoning religion.

For this study, the Brazil Religion Survey (hereinafter BRS) data is used. Datafolha conducted this survey in 2007. The sample includes 5,700 individuals, men and women older than sixteen years old, from all Brazilian regions. This survey is similar to the population distribution of the National Sample Survey of Households (PNAD) and the Demographic Census.

To achieve these objectives, this paper is divided into six sections. Theoretical aspects of secularization are discussed in the next section. The third section presents the source and treatment of the data along with descriptive statistics. Empirical models and estimation strategies form the fourth section. The fifth analyzes the results, followed by a discussion section, and, finally, conclusions are presented in section six.

\section{Theoretical and empirical aspects of secularization}

Secularization is the loss of authority and influence of religion in society, and occurs on three levels: macro (or social), meso (organizational) and micro (individual) (HALMAN; DRAULANS, 2006). An example of secularism at a social level is the autonomy of institutions, through the secularization of the state, the independence of education of ecclesiastical authorities, and the rejection of religious dogmas in relation to birth control and abortion (DOBBELAERE, 1999). Considering the meso level, there is the religious pluralism related to religious tolerance and relativism of religion, which leads to the impossibility of only one being correct (HALMAN; DRAULANS, 2006).

This paper focuses on the individual level of secularization. At this level, secularism appears in the individualization of religion, which happens when people make religious practice something private, unrelated to the rites practiced within the churches. There is also the individualization of choices when individuals make decisions based on their own beliefs, rather than considering what religions teach (DOBBELAERE, 1999; HALMAN; DRAULANS, 2006).

Two other manifestations of secularism at the individual level are disbelief and decline of religious practice. Every religion has its own set of beliefs, and they expect churchgoers to reinforce these doctrines. Thus, disbelief appears in the abandonment of traditional doctrines, which does not necessarily culminate in atheism (HALMAN; DRAULANS, 2006). The decline of religious practice can be a consequence of other aspects of secularization, especially disbelief (DOBBELAERE, 1999).

Secularization theorists agree that the primary cause of this phenomenon is the advance of modernity (STARK, 1991). Among the factors influencing the decline of religion, the literature highlights economic development, measured by GDP per capita (the macro level) or gross family income (micro level). Another recurrent hypothesis is the positive association between higher levels of education and a greater probability of religious disengagement (IANNACCONE, 1998). 
Urbanization also plays a key role in secularism because non-traditional religions spread faster due to communication and transportation facilities; that is, urbanization contributes to pluralism. In addition, urban areas offer more leisure options and social integration beyond the church, as observed by Brañas-Garza, García-Muñoz and Neuman (2008).

Secularization views changes in religiosity from changes in factors that affect religious demand. Therefore, the model proposed by Azzi and Ehrenberg (1975), Religious Household Production, is suitable to test the secularization hypothesis. It is a linear utility model that considers the allocation of time in secular activities (working out, for instance) and religious activities (such as attending church service). The key concept is the opportunity cost of the use of time, measured by the real wage. The theoretical formulation assumes that an increase in salary leads to a decrease in religious practice (BARRO; MCCLEARY, 2006).

From this model it is possible to explain the fact that women attend church more than men do - they have lower participation cost. Another hypothesis of this model refers to the age of the individuals, since younger people (in search for better job opportunities and consequently better salaries) invest more in secular than in religious activities.

Barro and McCleary (2003) used the Azzi and Ehrenberg (1975) framework with a sample data of 61 countries. They found that in countries with higher GDP per capita people are less religious. In a later study with data updated, Barro and McCleary (2006) confirmed this result.

For the research on how secular Europe is, Halman and Draulans (2006) used measures of belief and religious practice - frequency of attending church, frequency of prayer and volunteer work in religious institutions. The results of the multivariate analysis pointed out that having no religion and working out contributes to secularization at the individual level, while higher education levels were not significant in the religiosity of Europeans.

The fact of being married within religion (homogamic marriage) is associated to lower probabilities of apostasy. Brañas-Garza, García-Muñoz and Neuman (2008) used data from the International Social Survey Program (ISSP) from 1998, with a sample of 31 countries, and estimated the determining factors of religious disaffiliation. Being married to someone from the same religion was associated with lower likelihood of religion abandonment.

Some studies recognize the growth of Evangelicals in Brazil and the resulting pluralism can be a sign of secularization. ${ }^{1}$ According to Fonseca (2000), the religious revival that the country experiences leads individuals to break ties with the Catholic tradition, and this promotes the growth of non-religion. In the same study, the author used data from the 1991 Census and observed that the states of Rondônia, Espírito Santo, Rio de Janeiro, Goiás and Rio Grande do Sul, where there were more Evangelicals, also had a major presence of non-religious people.

\footnotetext{
${ }^{1}$ This paper does not emphasize macro or meso aspects of secularization to focus only in the micro level. To see how these changes influence the political context in Brazil (macro level), the reader is referred to Machado and Burity (2014), Prandi and Santos (2017), and Costa, Marcantonio Jr. and Castro (2018). At the meso level, the papers of Almeida and Montero (2001) and Montero (2009) are recommended.
} 
From an indicator of the ratio between Catholics and Evangelicals, Alves et al. (2017) analyzed the space distribution of the religious transition in the country between 1991 and 2010, and concluded an increase in religious pluralism and a tendency to change hegemony among Catholics and Evangelicals.

Using data from the 2000 Census and the 2003 Family Budget Survey (POF) to understand the religious flow in Brazil, Neri (2007) concluded that the poorest people in the rural area remain Catholics, while in the urban peripheries there is an intense migration toward the Evangelical segments and non-religion.

Moreira-Almeida et al. (2010) considered measures of religious involvement membership such as church attendance and the importance attributed to religion. In particular, in terms of demographic attributes, results in Brazil have been in line with those of other countries, particularly the United States, where women and elderly population are more involved with religion.

Oliveira et al. (2013) applied the Azzi and Ehrenberg (1975) model to the Brazilian Social Research (PESB) from 2004. They found associations between church attendance and demographic characteristics (gender and age) and socioeconomic (income). According to their results, women attend church more; religious participation increases with age; and higher levels of income are negatively related to church attendance.

Coutinho and Golgher (2014) analyzed the possible effects of age, period and cohort to explain the religious metamorphosis in Brazil with the hierarchical model of ageperiod - cohort and random effects models with cross-classification data for the last four Brazilian demographic census (1980, 1991, 2000 and 2010). The effects of age were substantial for the category without religion. Moreover, a positive relationship was found between post-secondary education and lack of religious affiliation.

The peculiarity of this paper is its consideration of secularization as the driving force of the change in the Brazilian religious scenario during the past decades. The Azzi and Ehrenberg (1975) framework is used, and the absence of religion and/or religiosity is estimated controlling by demographic, cultural, regional and socio-economic characteristics. Thus, this paper contributes to the debate in Economics of Religion in Brazil, providing empirical evidence to understand this issue from an economic approach.

\section{Data source and variables}

In order to analyze the religious behavior of the Brazilian population and to test the hypothesis of secularization, BRS data is used, a survey conducted by the Datafolha institute on 19 and 20 March 2007. The data were available at the site of the Association of Religious Data Archives. The usage of this database in any published study about religion in Brazil is unknown.

For data collection, Datafolha used a stratified random sample with quotas based on sex and age and random sample of individuals. The Brazilian population as a whole, 
sixteen years of age and older, is the universe of research, which was divided into four subuniverses, representing the Northeast, Southeast, South and North/Central-West regions. In each sub-universe, municipalities were selected randomly, with probability proportional to size. The margin of error for this sampling procedure is about two percentage points at a $95 \%$ confidence interval.

For the survey, 5.700 people were interviewed in 236 municipalities in almost every Brazilian state, except for Roraima and Amapá. The research explores various aspects about religion in Brazil, and allows for control by socioeconomic, geographic, demographic and cultural attributes.

One of the goals of this paper is to analyze the factors affecting the choice of disaffiliation. A variable was built to identify those who at the time of the survey had no religion, but in the past had belonged to some religion, in contrast to those who have had a religion before and remained affiliated to some religion at the time of the survey. To construct this variable, measures to identify the current and the previous religion ${ }^{2}$ of the interviewed were built first.

In the original database, religions were presented in nine categories, named: Pentecostal Evangelical, Evangelical not Pentecostal, Umbanda, Candomble or other AfricanBrazilian religions, Kardecian Spiritism or Spiritualism, Catholic, Judaism, Other (Mormons, Jehovah's Witnesses, Adventists, Buddhists, etc.), and without religion (including atheists). Because of the representation and the similarity between Umbanda and Candomble or other African-Brazilian religions, these categories were regrouped in Afro-Brazilian religions.

Table 1 presents the distribution of current and past religions. Considering the previous religion, notice that $72 \%$ of interviewees had Catholic religion as prior religion, while $15 \%$ followed the Evangelical faith (Pentecostal or non-Pentecostal), and 6.5\% had no religion before. Judaism, Spiritism, Afro-Brazilian and Other religions amounted to approximately $6 \%$ of the sample.

Regarding the current religion, Judaism and other religions add up to $2.8 \%$ of the population. The number of members from Afro-Brazilian religions and Spiritism - about $6 \%$ of the sample - is possibly due to the fact that many people affiliated to these religions has dual religious identity; one public (Catholic) and the other private - Spiritualism, Umbanda, Candomble (ALMEIDA; MONTERO, 2001).

Note also that $82.7 \%$ of Brazilian people belong to the Catholic and Evangelical religions, whereas $8.5 \%$ of respondents have no religion. From this analysis between current and previous religion, it is remarkable that there is a religious transition movement in the country.

To capture disbelief, the following questions are considered:

- Would you say that you totally believe, have doubts or do not believe that God exists?

\footnotetext{
${ }^{2}$ Current in the sense of the religion professed by the respondent at the time of the survey. The former religion does not necessarily correspond to the religion in which the person was born.
} 
- Would you say that you totally believe, have doubts or do not believe that after death some people go to heaven?

- Would you say that you totally believe, have doubts or do not believe that after death some people go to hell?

The answers were categorized into one for those who believe and zero for those who have any questions or do not believe. Thus, it was decided to change the form of categorization to capture disbelief assigning value of one to those who doubt or do not believe and zero for those who believe.

TABLE 1

Distribution of current and previous religions of Brazilians - 2007

\begin{tabular}{lrrrrr}
\hline \multirow{2}{*}{ Religion } & \multicolumn{2}{c}{ Previous } & & \multicolumn{2}{c}{ Current } \\
\cline { 2 - 3 } \cline { 5 - 5 } & $\mathbf{N}$ & N & & N & \% \\
\hline Catholic & 4,040 & 71.58 & & 3,362 & 58.98 \\
Evangelical Pentecostal & 668 & 11.84 & & 1,049 & 18.40 \\
No religion & 367 & 6.50 & & 488 & 8.56 \\
Evangelical non-Pentecostal & 222 & 3.93 & 303 & 5.32 \\
Spiritism & 141 & 2.50 & & 238 & 4.18 \\
Other & 105 & 1.96 & & 151 & 2.65 \\
Afro-Brazilian & 91 & 1.61 & & 98 & 1.72 \\
Judaism & 10 & 0.18 & & 11 & 0.19 \\
Total & 5,644 & 100.00 & & 5,700 & 100.00 \\
\hline
\end{tabular}

Source: Brazil Religion Survey (2007).

Regarding the absence of religious practice, the variables are of ordinal character and give lower values referring to a higher frequency of religious activities (pray/go to church or religious services) and higher values to low frequency in these activities. The categories "Does not usually go to church" and "Goes to church less than once a year" were grouped into one, denominated simply "Does not usually go to church"; this arrangement aims to facilitate the presentation of results. It should be noted thatin Table 2, $12.67 \%$ of respondents do not usually go to church, while $5.7 \%$ reported not to pray. On the other hand, $26.78 \%$ said they attend church more than once a week, while $71.49 \%$ pray every day.

TABLE 2

Frequency of church attendance and prayer of Brazilians - 2007

\begin{tabular}{clrr|lrr}
\hline Values & $\begin{array}{c}\text { Frequency of church } \\
\text { attendance }\end{array}$ & $\mathbf{N}$ & \% & \multicolumn{1}{|l}{ Frequency of prayer } & N & $\%$ \\
\hline 1 & More than once a week & 1,524 & 26.78 & Every day & 4,065 & 71.49 \\
2 & Once a week & 1,663 & 29.23 & Almost everyday & 720 & 12.66 \\
3 & Once every 15 days & 485 & 8.52 & At least once a week & 397 & 6.98 \\
4 & Once a month & 753 & 13.23 & Once every 15 days & 63 & 1.11 \\
5 & Once every six months & 305 & 5.36 & Once a month & 76 & 1.34 \\
6 & Once a year & 239 & 4.20 & Less than once a month & 41 & 0.72 \\
7 & Do not usually go to churches & 721 & 12.67 & Do not pray & 324 & 5.70 \\
\hline Total & & $\mathbf{5 , 6 9 0}$ & $\mathbf{1 0 0 . 0 0}$ & & $\mathbf{5 , 6 8 6}$ & $\mathbf{1 0 0 . 0 0}$ \\
\hline
\end{tabular}

Source: Brazil Religion Survey (2007). 
According to the hypotheses appointed in the literature, the independent variables include gender, age, marital status (whether married or not), the fact of being or having been married to someone from a different religion, formal education, family income and religious affiliation (previous and current). Table 3 presents the description of the variables.

TABLE 3

Set of characteristics (demographic, socioeconomic, cultural and geographical) considered in the analysis of religious secularization in Brazil

\begin{tabular}{|c|c|}
\hline Variable & Description \\
\hline \multicolumn{2}{|l|}{ Demographic } \\
\hline Male & 1 if male and 0 if female \\
\hline Age $1^{\star}$ & 1 if between 16 and 24 years old, and 0 otherwise \\
\hline Age 2 & 1 if between 25 and 34 years old, and 0 otherwise \\
\hline Age 3 & 1 if between 35 and 44 years old, and 0 otherwise \\
\hline Age 4 & 1 if between 45 and 59 years old, and 0 otherwise \\
\hline Age 5 & 1 if over 60 years old, and 0 otherwise \\
\hline Married & 1 if married (or legally cohabitating), and 0 otherwise \\
\hline Interreligion marriage & 1 if married to someone of another religion, and 0 otherwise \\
\hline \multicolumn{2}{|l|}{ Socioeconomic } \\
\hline Illiterate & 1 if illiterate, and 0 otherwise \\
\hline Elementary School & 1 if elementary education (complete or incomplete), and 0 otherwise \\
\hline High school & 1 if high school (complete or incomplete), and 0 otherwise \\
\hline Higher Education* & 1 if at least incomplete higher education, and 0 otherwise \\
\hline Income 1 ( $\$ 0$ to $\$ R 700)$ & $\begin{array}{l}1 \text { if household gross income is up to two minimum wages } \\
\text { otherwise }\end{array}$ \\
\hline Income 2 ( R \$701 to R \$1,750) & $\begin{array}{l}1 \text { if household gross income is between two and five minimum wages, and } \\
0 \text { otherwise }\end{array}$ \\
\hline Income $3(\mathrm{R} \$ 1,751$ to $\mathrm{R} \$ 3,500)$ & $\begin{array}{l}1 \text { if household gross income is between five and ten times the minimum } \\
\text { wage, and } 0 \text { otherwise }\end{array}$ \\
\hline Income 4 (over US \$3,500)* & $\begin{array}{l}1 \text { if household gross income is more than ten times the minimum wage, } \\
\text { and } 0 \text { otherwise }\end{array}$ \\
\hline PEA & 1 if belongs to the economically active population, and 0 otherwise \\
\hline \multicolumn{2}{|r|}{ 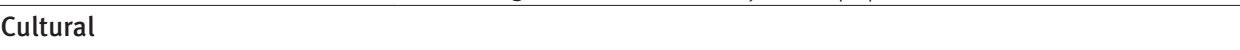 } \\
\hline Abortion & 1 if favorable to abortion in more cases or in any situation, and 0 otherwise \\
\hline Homosexual Marriage & 1 if favorable to legalization of homosexual union, and 0 otherwise \\
\hline Adoption & 1 if favorable to child adoption by homosexual couples, and 0 otherwise \\
\hline Prior Catholic & 1 if the former religion was Catholic, and 0 otherwise \\
\hline Prior Evangelical Pentecostal & 1 if the previous religion was Evangelical Pentecostal, and 0 otherwise \\
\hline Prior Evangelical non-Pentecostal & 1 if the previous religion was Evangelical non-Pentecostal, and 0 otherwise \\
\hline No prior religion & 1 if had no religion before, and 0 otherwise \\
\hline Catholic & 1 if the current religion is Catholic, and 0 otherwise \\
\hline Evangelical Pentecostal & 1 if the current religion is Evangelical Pentecostal, and 0 otherwise \\
\hline Evangelical non-Pentecostal & $\begin{array}{l}1 \text { if the current religion is Evangelical non-Pentecostal religion, and } 0 \\
\text { otherwise }\end{array}$ \\
\hline No Religion & 1 if currently has no religious affiliation, and 0 otherwise \\
\hline Religious institution & 1 if studying / studied in a religious institutions, and 0 otherwise \\
\hline
\end{tabular}

Geographical

Southeast

1 if residing in the Southeast region, and 0 otherwise 


\begin{tabular}{ll}
\hline Variable & Description \\
\hline South & 1 if residing in the South region, and 0 otherwise \\
Northeast & 1 if residing in the Northeast region, and 0 otherwise \\
North / Midwest* & 1 if residing in the North / Midwest region, and 0 otherwise \\
Metropolitan & 1 if living in the capital or in the metropolitan area, and 0 otherwise \\
\hline
\end{tabular}

Source: Brazil Religion Survey (2007).

* Denotes the variable of comparison.

The fact of studying or having studied in religious institutions was considered as a proxy for contact with religion in childhood or adolescence. This paper also considers the issue of inter-religion marriage, which BRS addresses with the question: "Have you ever dated or married someone of a different religion from yours?" The answers were grouped into one for those who married someone from another religion, and zero if they never dated or married someone from another religion / dated someone from another religion but did not get married. ${ }^{3}$

According to Azzi and Ehrenberg (1975), working implies cost of opportunity for religious involvement. The variable used to measure the effect of working concerns the economically active population (hereinafter PEA). Seeking work is also considered in this variable because it is an activity that demands time which could be allocated to religious activities.

lannaccone (1998) highlighted that having a liberal view on moral issues can cause people to feel uncomfortable in traditional churches, leading them to abandon religion. To capture this effect, the opinion of interviewees about abortion (agree to allow it in more cases) is considered, as well as opinion on homosexual unions and adoption of children by homosexual couples. Those who answered to be in favor of any of these, were assigned value one, while those who claimed to be against them were assigned value zero.

Considering the descriptive statistics in Table 4, it should be noted that $5.37 \%$ of the sample corresponds to those who have had a religion and currently do not. Those who do not believe in God amount to $3.31 \%$, while those who do not believe that some people go to heaven or hell after death constitute $37.37 \%$ and $44.38 \%$, respectively.

Regarding demographic attributes, we noted that that $47.96 \%$ of respondents are male, and adolescents and adults up to 34 years old account for almost half of the sample. The groups corresponding to ages between 34 and 44, 45 and 60 and over 60 years old constitute $20 \%, 18.9 \%$ and $12.9 \%$ of the sample, in this order. Almost $46.6 \%$ of interviewees are married or legally cohabitating and $8.5 \%$ have already married someone of a different religion.

\footnotetext{
${ }^{3}$ Note that it is not possible to know how many times the respondent was married, and if the current spouse is who has different religion, or if it was the former spouse. The effect of living with someone of another religion was admitted to remain even after the divorce.
} 
TABLE 4

Descriptive statistics of the variables considered for the analysis of secularization in Brazil

\begin{tabular}{|c|c|c|}
\hline Variables & Mean & Standard deviation \\
\hline Disaffiliated & 0.0537 & 0.2256 \\
\hline No God & 0.0331 & 0.1789 \\
\hline No Heaven & 0.3737 & 0.4838 \\
\hline No Hell & 0.4438 & 0.4968 \\
\hline No church & 3.0444 & 2.0284 \\
\hline No prayer & 1.7309 & 1.5548 \\
\hline Male & 0.4796 & 0.4996 \\
\hline Age 1 & 0.2514 & 0.4338 \\
\hline Age 2 & 0.2289 & 0.4201 \\
\hline Age 3 & 0.2005 & 0.4004 \\
\hline Age 4 & 0.1894 & 0.3919 \\
\hline Age 5 & 0.1296 & 0.3359 \\
\hline Married & 0.4667 & 0.4989 \\
\hline Inter-religion & 0.0855 & 0.2797 \\
\hline Income 1 & 0.4233 & 0.4941 \\
\hline Income 2 & 0.3840 & 0.4864 \\
\hline Income 3 & 0.1244 & 0.3300 \\
\hline Income 4 & 0.0682 & 0.2522 \\
\hline Illiterate & 0.0369 & 0.1886 \\
\hline Elementary education & 0.4225 & 0.4940 \\
\hline High school & 0.4090 & 0.4917 \\
\hline Higher education & 0.1314 & 0.3378 \\
\hline PEA & 0.6891 & 0.4628 \\
\hline Religious institution & 0.1813 & 0.3853 \\
\hline Homosexual marriage & 0.4389 & 0.4963 \\
\hline Adoption & 0.4466 & 0.4971 \\
\hline Abortion & 0.7063 & 0.4554 \\
\hline Evangelical Pentecostal & 0.1840 & 0.3875 \\
\hline Evangelical non-Pentecostal & 0.0531 & 0.2243 \\
\hline Catholic & 0.5898 & 0.4919 \\
\hline No religion & 0.0856 & 0.2798 \\
\hline Prior Catholic & 0.1183 & 0.3230 \\
\hline Prior Evangelical Pentecostal & w0.0393 & 0.1944 \\
\hline Prior Evangelical non-Pentecostal & 0.7158 & 0.4510 \\
\hline No prior religion & 0.0650 & 0.2465 \\
\hline South & 0.0684 & 0.2524 \\
\hline Northeast & 0.1215 & 0.3268 \\
\hline Southeast & 0.7436 & 0.4366 \\
\hline North / Midwest & 0.0663 & 0.2488 \\
\hline Metropolitan & 0.5836 & 0.4929 \\
\hline
\end{tabular}

Source: Brazil Religion Survey (2007).

The family income of $42.33 \%$ of the interviewed is at the most two minimum wages, while $38.4 \%$ have an income amounting to between two and five minimum wages. Those whose family income is between five and ten minimum wages correspond to $12.44 \%$, and 
$6.8 \%$ of the respondents earn over 10 minimum wages. Almost $69 \%$ of the sample belong to PEA. Note that $3.6 \%$ of the interviewed are illiterate, $42.25 \%$ have complete or incomplete elementary education, $40.9 \%$ are attending or have finished high school, and $13.14 \%$ are at least attending higher education.

Considering cultural aspects, $18.13 \%$ of the sample study or have studied in a religious institution. And $43.9 \%$ are in favor of homosexual unions, $44.66 \%$ are in favor of child adoption by homosexual couples and $70.63 \%$ support allowing abortion in more situations or in any case.

Specifically in the Brazilian case, there is evidence, as in Coutinho and Golgher (2014), that it is necessary to control religious demand for macro-regions. The BRS interviewed people in the South, Northeast and Southeast macro-regions, and added North / Midwest. In percentage terms, $6.84 \%$ are in the South, $12.15 \%$ in the Northeast, $74.36 \%$ in the Southeast and $6.63 \%$ in the North and Midwest regions. The research also contemplates information regarding the municipality of interviewees, whether the location is in the metropolitan region, in the capital or in the countryside. Thus, capital and metropolitan regions were grouped to be compared with the countryside, assuming the values one and zero, respectively. Note that $58.36 \%$ of respondents reside in the capital or in the metropolitan region.

\section{Econometric model and empirical strategy}

To analyze whether Brazilian population presents secular behavior, models of discrete choice are used. According to Greene (2003), these models prescribe that the probability of an individual making the right choice depends on their socioeconomic characteristics. It is important to notice that the choice of secularization can also be influenced by individuals' demographic, geographic and cultural characteristics.

The framework of choice considers the option of individual $i$ relative to $j$ possible alternatives. Choices are mutually exclusive and exhaustive. That is, the choice of one alternative excludes the possibility of another, and one of the alternatives must be chosen.

The disaffiliation compares two types of individuals: those who have had a religion and currently do not have any, and those who had a religion before and continue to profess some religion. Therefore, a model of binary choice applies, where the variable assumes value one if the individual has disaffiliated, and zero for individuals currently affiliated to some religion.

In the case of unbelief, three models are considered: disbelief in the existence of God, that after death, some people go to heaven, and that some people after death go to hell. If the answer is negative - that is, the person believes in God, in an afterlife in Heaven or Hell - the default value is zero, while those who do not believe or are unsure receive value one.

Thus, in the case of disaffiliation and of disbelief, the Probit model is used, which assumes that the distribution of the error term follows a normal distribution, and has a cumulative distribution function given by: 
$G(z)=\int_{-\infty}^{z} \varphi(z) d z=\Phi(z)$

Whereas its probability distribution function is described by:

$g(z)=\sqrt{2 \pi \cdot e^{z^{2}}}=\varphi(z)$

In the case of not attending church or religious services, the frequency alternatives represent qualitative results to express the fact of attending church or not, and ordered based on a ranking constructed from frequency in descending order. Those who do not attend church receive value eight, whereas those who attend more than once a week assume value one (see Table 2).

The lack of praying habits is also assessed with a qualitative variable expressing an ordered ranking, assigning a value of seven if the individual does not have a praying habit and value one for those who pray every day. Therefore, to estimate the lack of habit to go to church or worship or religious services, and the lack of praying habit, the Ordered Probit model is used.

In this case, as $y$ is a choice from the responses provided by interviewees and assumes the values one, two, ..., seven in case of absence of a praying habit, and one, two, ... eight in the case of lacking the habit of going to church, the model to be estimated has the following specification:

$\operatorname{Pr} o b(y=J \mid x)=\operatorname{Prob}\left(y^{\star}>\alpha_{j} \mid x\right)=1-\Phi\left(\alpha_{J-1}-x \beta\right)$

Where $\alpha$ is the frequency of church attendance and prayer, $J$ is each of the frequency options of individuals, $X$ is a vector of socioeconomic, demographic, geographic and cultural characteristics, and $\beta$ is a pair of vector parameters to be estimated.

Finally, it should be noted that the analysis and discussion of the results for these secularization models, which were estimated by Probit and Ordered Probit, will be done from the marginal effects.

\section{Results}

In this section, the marginal effects of the models are presented, and the evidences checked with the existing literature. Table 5 below reports results for the models of disaffiliation and disbelief. Considering the model of disaffiliation first, we noted that being male increases the chances of disaffiliation in 2.41 percentage points (pp). Coutinho and Golgher (2014) also found men more prone to not having a religion. However, they made no distinction between those who disaffiliated and those who had never had any religion.

Regarding the socioeconomic variables, it must be noted that people with elementary school education level have lower chances of abandoning religion (2.18 pp). As for geographical characteristics, the fact of living in the Northeast region decreases the likelihood of disaffiliation by $1.5 \mathrm{pp}$. 
The religion to which the person belongs helps predict the likelihood to disaffiliate: those who declared to be Evangelical Pentecostal are more prone to abandoning religion, with a probability of $5.74 \mathrm{pp}$. No other cultural aspect has proven significant.

With regard to disbelief models, we observed that being male increases the chances of not believing that God exists in $1.58 \mathrm{pp}$. It is also remarkable that no socioeconomic characteristics were significant for this model, i.e., income, education, and belonging to the PEA does not correlate with disbelief in the existence of God.

With regard to geographical variables, it appears that individuals who live in the metropolitan area or in the capital (possibly more urbanized places compared to the countryside) have a chance of $1.14 \mathrm{pp}$ of not believing that God exists, confirming the secularist hypothesis.

Being favorable to abortion in more situations or in any case has a negative impact on disbelief, decreasing the chances of not believing in the existence of God in $1.16 \mathrm{pp}$, which is a result contrary to what was expected. Still, in relation to cultural characteristics, the current religion is an important predictor of the levels of disbelief. Being Evangelical, Pentecostal or non-Pentecostal, decreases the chances of not believing that God exists at 1.31 and $0.94 \mathrm{pp}$, respectively; on the other hand, not having any religion increases the odds by 3.80 pp.

As for believing that some people go to heaven after death, the findings show that older individuals have a higher propensity to disbelief; being between 45 and 59 years old increases the likelihood of disbelief in $10.41 \mathrm{pp}$ and being over 60 years increases it in $8.41 \mathrm{pp}$.

Analyzing the geographical aspects, living in the metropolitan area or in the capital increases the chances of not believing that people go to heaven after death by $4.46 \mathrm{pp}$. Cultural aspects also help explain disbelief. People who claim to be favorable to allowing abortion in more situations or in any case are less likely to believe that some people do not go to heaven in 7.02 pp. Being Catholic and Evangelical (Pentecostal or not) diminishes the chance of not believing that people go to heaven in 14.89 pp, 27.67 and 28.28, respectively.

Regarding the belief that some people go to hell after death, all age groups appeared to be significant: being between 25 and 34 increases the propensity to disbelief in $6.37 \mathrm{pp}$; between 35 and 44, in 8.41 pp; between 45 and 59, 8.20 pp; and above 60 in 8.45 pp.

Among the socioeconomic attributes, the variable referring to elementary education levels decreases the probability of disbelief in $8.79 \mathrm{pp}$. Now with regard to the geographical aspects, living in the South and Southeast regions increases the odds of not believing that after death some people go to hell in 11.64 and $8.71 \mathrm{pp}$, respectively.

Being supportive of child adoption by homosexual couples increases the likelihood of disbelief by $4.70 \mathrm{pp}$, while being favorable to the liberalization of abortion in more cases or in any situation decreases the likelihood in 7.54 pp. Being Catholic or Evangelical (Pentecostal or not) decreases the chances of disbelief in 15.61, 34.76 pp and $27.08 \mathrm{pp}$. 
TABLE 5

Marginal effects of religious disaffiliation, not believing in God and not believing that some people go to Heaven or Hell after death models

\begin{tabular}{|c|c|c|c|c|}
\hline Variable & Disaffiliation & No God & No Heaven & No Hell \\
\hline Male & $0.0241^{\star}$ & $0.0158^{*}$ & -0.0142 & -0.0246 \\
\hline Age 2 & -0.0052 & -0.0011 & 0.0529 & $0.0637^{\star}$ \\
\hline Age 3 & 0.0045 & -0.0063 & 0.0496 & $0.0841^{*}$ \\
\hline Age 4 & -0.0057 & 0.0001 & $0.1041^{*}$ & $0.0820^{*}$ \\
\hline Age 5 & -0.0072 & -0.0062 & $0.0841^{*}$ & $0.0845^{\star}$ \\
\hline Married & -0.0119 & -0.0048 & -0.0099 & -0.0025 \\
\hline Inter-religion marriage & -0.0070 & -0.0007 & 0.0068 & 0.0407 \\
\hline Income 1 & -0.0179 & -0.0075 & -0.0169 & -0.0350 \\
\hline Income 2 & -0.0179 & -0.0041 & 0.0007 & -0.0104 \\
\hline Income 3 & -0.0128 & 0.0009 & 0.0790 & 0.0573 \\
\hline Illiterate & -0.0182 & 0.0027 & -0.0665 & -0.0350 \\
\hline Elementary education & $-0.0218^{\star}$ & -0.0034 & -0.0461 & $-0.0879 *$ \\
\hline High school & -0.0192 & -0.0003 & 0.0037 & -0.0432 \\
\hline PEA & 0.0041 & -0.0058 & 0.0300 & 0.0234 \\
\hline Metropolitan & 0.0103 & $0.0114^{*}$ & $0.0446^{\star}$ & 0.0348 \\
\hline South & -0.0134 & 0.0225 & 0.0492 & $0.1164^{*}$ \\
\hline Northeast & $-0.0231^{\star}$ & 0.0044 & -0.0275 & 0.0651 \\
\hline Southeast & -0.0100 & -0.0017 & -0.0028 & $0.0871^{\star}$ \\
\hline Homosexual Marriage & 0.0145 & 0.0063 & 0.0417 & 0.0036 \\
\hline Adoption & 0.0090 & -0.0046 & 0.0121 & $0.0470^{\star}$ \\
\hline Abortion & -0.0050 & $-0.0116^{\star}$ & $-0.0702^{\star}$ & $-0.0754^{*}$ \\
\hline Religious institution & -0.0035 & 0.0122 & -0.0245 & 0.0004 \\
\hline Prior Catholic & -0.0115 & 0.0024 & -0.0331 & -0.0629 \\
\hline Prior Evangelical Pentecostal & $0.0574^{*}$ & -0.0038 & -0.0312 & -0.0640 \\
\hline Prior Evangelical non-Pentecostal & 0.0490 & 0.0066 & 0.0434 & -0.0996 \\
\hline No prior religion & & 0.0131 & 0.0549 & -0.0114 \\
\hline Catholic & & -0.0100 & $-0.1489^{\star}$ & $-0.1561^{\star}$ \\
\hline Evangelical Pentecostal & & $-0.0131^{*}$ & $-0.2767^{\star}$ & $-0.3476^{\star}$ \\
\hline Evangelical non-Pentecostal & & $-0.0094^{\star}$ & $-0.2828^{\star}$ & $-0.2708^{\star}$ \\
\hline No religion & & $0.0380^{*}$ & 0.0334 & -0.0090 \\
\hline
\end{tabular}

Source: Brazil Religion Survey (2007).

* Denotes statistical significance at the $5 \%$ level (p-value $<0.05$ ).

Now with regard to the model in Table 6 below, related to the lack of church attendance, note that, as inferred by Azzi and Ehrenberg (1975), men are less prone to attending church more often (considering "often" as at least once a week). In this case, they are more prone to attending once a month - the odds for this being $2.21 \mathrm{pp}$.

With regard to age, it is remarkable that the variable referring to the age of 60 was significant for all frequencies, increasing the likelihood of attending church at least once a week. For those with ages between 45 and 59 years old, there is an increase in this probability at $1.28 \mathrm{pp}$, as well as a lower chance of not going to church by $1.74 \mathrm{pp}$. Oliveira, Cortes and Neto (2013) also found that, as people grow older, they tend to go to church more often. 
The fact of having married someone of another religion affects church attendance: it diminishes the chances of attending more than once a week at $6.83 \mathrm{pp}$ and of attending once a week at $3.59 \mathrm{pp}$. This corroborates the finding of Williams and Lawler (2001) that people in heterogamic marriages are less religiously active.

TABLE 6

Marginal effects of the lack of church attendance model

\begin{tabular}{|c|c|c|c|c|c|c|c|}
\hline Frequency & $\begin{array}{c}\text { More than } \\
\text { once a } \\
\text { week }\end{array}$ & $\begin{array}{c}\text { Once a } \\
\text { week }\end{array}$ & $\begin{array}{c}\text { Once } \\
\text { every } 15 \\
\text { days }\end{array}$ & $\begin{array}{l}\text { Once a } \\
\text { month }\end{array}$ & $\begin{array}{c}\text { Once } \\
\text { every six } \\
\text { months }\end{array}$ & $\begin{array}{c}\text { Once a } \\
\text { year }\end{array}$ & $\begin{array}{l}\text { Does not } \\
\text { usually go } \\
\text { to church }\end{array}$ \\
\hline Variable & 1 & 2 & 3 & 4 & 5 & 6 & 7 \\
\hline Male & $-0.0582^{\star}$ & $-0.0218^{\star}$ & $0.0060^{*}$ & $0.0221 *$ & $0.0121^{\star}$ & $0.0117^{\star}$ & $0.0279^{\star}$ \\
\hline Age 2 & -0.0162 & -0.0064 & 0.0016 & 0.0061 & 0.0034 & 0.0033 & 0.0080 \\
\hline Age 3 & 0.0079 & 0.0028 & -0.0008 & -0.0030 & -0.0016 & -0.0015 & -0.0037 \\
\hline Age 4 & 0.0403 & $0.0128^{\star}$ & -0.0046 & -0.0153 & $-0.0080^{*}$ & $-0.0076^{*}$ & $-0.0174^{\star}$ \\
\hline Age 5 & $0.0941^{*}$ & $0.0213^{*}$ & $-0.0122^{*}$ & $-0.0351^{*}$ & $-0.0173^{*}$ & $-0.0158^{*}$ & $-0.0346^{\star}$ \\
\hline Married & -0.0029 & -0.0011 & 0.0003 & 0.0011 & 0.0006 & 0.0005 & 0.0014 \\
\hline Inter-religion marriage & $-0.0683^{*}$ & $-0.0359^{\star}$ & $0.0049^{\star}$ & $0.0255^{\star}$ & $0.0156^{\star}$ & $0.0160^{*}$ & $0.0421^{\star}$ \\
\hline Income 1 & 0.0384 & 0.0141 & -0.0040 & -0.0146 & -0.0079 & -0.0077 & -0.0181 \\
\hline Income 2 & 0.0136 & 0.0050 & -0.0014 & -0.0052 & -0.0028 & -0.0027 & -0.0064 \\
\hline Income 3 & 0.0032 & 0.0011 & -0.0003 & -0.0012 & -0.0006 & -0.0006 & -0.0015 \\
\hline Illiterate & $-0.0742^{\star}$ & -0.0415 & $0.0047^{\star}$ & $0.0275^{\star}$ & $0.0173^{*}$ & $0.0179 *$ & 0.0483 \\
\hline Elementary School & -0.0148 & -0.0056 & 0.0015 & 0.0056 & 0.0031 & 0.0030 & 0.0071 \\
\hline High school & -0.0073 & -0.0027 & 0.0007 & 0.0027 & 0.0015 & 0.0015 & 0.0035 \\
\hline PEA & $-0.0324^{\star}$ & $-0.0112^{\star}$ & 0.0035 & $0.0123^{\star}$ & $0.0066^{\star}$ & $0.0063^{*}$ & $0.0147^{\star}$ \\
\hline Metropolitan & 0.0030 & 0.0011 & -0.0003 & -0.0011 & -0.0006 & -0.0006 & -0.014 \\
\hline South & $-0.0994^{*}$ & $-0.0560^{\star}$ & $0.0060^{\star}$ & $0.0365^{\star}$ & $0.0231^{*}$ & $0.0240^{\star}$ & $0.0656^{\star}$ \\
\hline Northeast & $-0.0608^{*}$ & $-0.0268^{\star}$ & $0.0055^{\star}$ & $0.0230^{*}$ & $0.0132^{\star}$ & $0.0131^{*}$ & $0.0326^{*}$ \\
\hline Southeast & $-0.0503^{*}$ & $-0.0196^{\star}$ & $0.0051^{*}$ & $0.0191^{*}$ & $0.0106^{\star}$ & $0.0103^{*}$ & $0.0247^{\star}$ \\
\hline Homosexual Marriage & $-0.0497^{\star}$ & $-0.0192^{\star}$ & $0.0050^{*}$ & $0.0189^{\star}$ & $0.0104^{\star}$ & $0.0101^{*}$ & $0.0243^{*}$ \\
\hline Adoption & -0.0095 & -0.0035 & 0.0009 & 0.0036 & 0.0019 & 0.0019 & 0.0045 \\
\hline Abortion & $0.0379^{\star}$ & $0.0157^{\star}$ & $-0.0036^{\star}$ & $-0.0144^{\star}$ & $-0.0081^{\star}$ & $-0.0080^{\star}$ & $-0.0194^{\star}$ \\
\hline Religious institution & 0.0188 & 0.0065 & -0.0020 & -0.0071 & -0.0038 & -0.0037 & -0.0085 \\
\hline Prior Catholic & -0.0455 & -0.0148 & 0.0052 & 0.0173 & 0.0091 & 0.0087 & 0.0199 \\
\hline Prior Evangelical Pentecostal & -0.0339 & -0.0148 & 0.0031 & 0.0129 & 0.0073 & 0.0073 & 0.0180 \\
\hline $\begin{array}{l}\text { Prior Evangelical non- } \\
\text { Pentecostal }\end{array}$ & $-0.0775^{\star}$ & -0.0439 & $0.0047^{\star}$ & $0.0286^{\star}$ & 0.0181 & 0.0188 & 0.0511 \\
\hline No prior religion & -0.0419 & -0.0195 & 0.0036 & 0.0158 & 0.0092 & 0.0093 & 0.0234 \\
\hline Catholic & $-0.0926^{\star}$ & $-0.0290^{\star}$ & $0.0106^{\star}$ & $0.0349^{\star}$ & $0.0183^{\star}$ & $0.0175^{\star}$ & $0.0401^{\star}$ \\
\hline Evangelical Pentecostal & $0.2503^{\star}$ & $0.0207^{\star}$ & $-0.0358^{\star}$ & $-0.0872^{\star}$ & $-0.0398^{\star}$ & $-0.0356^{\star}$ & $-0.0724^{\star}$ \\
\hline Evangelical non-Pentecostal & $0.2272^{\star}$ & 0.0073 & $-0.0342^{\star}$ & $-0.0782^{\star}$ & $-0.0343^{*}$ & $-0.0299^{\star}$ & $-0.0577^{\star}$ \\
\hline No religion & $-0.2478^{\star}$ & $-0.3258^{*}$ & $-0.0721^{\star}$ & $-0.0493^{\star}$ & $0.0217^{\star}$ & $0.0529^{\star}$ & $0.6204^{*}$ \\
\hline
\end{tabular}

Source: Brazil Religion Survey (2007)

* Denotes statistical significance at the $5 \%$ level (p-value $<0.05)$. 
The fact of not having formal education reduces the chances of attending more than once a week for $7.42 \mathrm{pp}$ and of attending once a month in $2.75 \mathrm{pp}$, in comparison to those who have at least higher education. It was also noted that those working or seeking employment are less prone to attending church at least once a week.

With regard to the Brazilian macro-regions, we observed that the trend is not to attend at least once per week. Regarding cultural aspects, being in favor of homosexual couples affects all frequency bands, increasing the chances of not going to church. In this case, the probability of attending church more than once a week is negative of magnitude $4.97 \mathrm{pp}$. Moreover, being supportive of allowing abortion in more situations or in any case decreases the odds of not going to church; the odds for going more than once a week is $3.79 \mathrm{pp}$.

In relation to the current religion, being Evangelical (Pentecostal or not) increases the likelihood of attending at least once a week, whereas being Catholic and having no religion diminishes the likelihood of attending at least once a week. In summary, Evangelicals are more frequent than Catholics and Catholics are more frequent than those without religion. This result differs from that of Irffi, Cruz and Carvalho (2017) for Brazilian women which pointed out that the religion in which the woman had been raised was more important to explain church attendance than current religious affiliation.

Finally, with regard to the estimation of the lack of praying habits, showed in Table 7 below, it should be noted that males are less likely to pray every day. Note also that for all age groups the effect is positive for having the habit of praying every day. The fact of being married to someone from another religion decreases the chances of praying daily in $7.46 \mathrm{pp}$.

Socioeconomic characteristics do not appear to be related to the habit of praying. On the other hand, people who live in the metropolitan area or in the capital are less likely to pray every day - the odds for this are of $3.75 \mathrm{pp}$, and it increases the chance of not having the habit of praying in $0.88 \mathrm{pp}$. Those living in the Southern region are more prone to praying almost every day.

With regard of cultural variables, being in favor of allowing abortions in more cases or in any situation presents a significant effect on all frequency bands, increasing propensity to praying daily at $5.72 \mathrm{pp}$. and reducing the propensity to not praying at $1.39 \mathrm{pp}$.

Non-Pentecostal Evangelicals are less likely to lack prayer habits with odds of $1.75 \mathrm{pp}$. Belonging to the Evangelical Pentecostal religion diminishes the chance of not having the habit of praying in $1.92 \mathrm{pp}$, and increases the chances of praying daily at $9.28 \mathrm{pp}$. Furthermore, having no religion decreases the chances of praying every day at $36.03 \mathrm{pp}$ and increases the chances of not having a prayer habit at $14.75 \mathrm{pp}$. This result is similar to that of Halman and Draulans (2006) that saw the importance of religion to explain the intensity of religious practice. 
TABLE 7

Marginal effects of the lack of prayer model

\begin{tabular}{|c|c|c|c|c|c|c|c|}
\hline Frequency & Everyday & $\begin{array}{l}\text { Almost } \\
\text { everyday }\end{array}$ & $\begin{array}{c}\text { At least } \\
\text { once a } \\
\text { week }\end{array}$ & $\begin{array}{c}\text { Once } \\
\text { every } 15 \\
\text { days }\end{array}$ & $\begin{array}{l}\text { Once a } \\
\text { month }\end{array}$ & $\begin{array}{c}\text { Less than } \\
\text { once a } \\
\text { month }\end{array}$ & $\begin{array}{c}\text { Do not } \\
\text { pray }\end{array}$ \\
\hline Variable & 1 & 2 & 3 & 4 & 5 & 6 & 7 \\
\hline Male & $-0.1542^{\star}$ & $0.0549^{\star}$ & $0.0413^{*}$ & $0.0081^{\star}$ & $0.0096^{*}$ & $0.0038^{\star}$ & $0.0366^{*}$ \\
\hline Age 2 & $0.0488^{\star}$ & $-0.0183^{\star}$ & $-0.0132^{\star}$ & $-0.0025^{\star}$ & $-0.0029^{\star}$ & -0.0012 & $-0.0108^{\star}$ \\
\hline Age 3 & $0.0854^{\star}$ & $-0.0330^{\star}$ & $-0.0230 *$ & $-0.0043^{\star}$ & $-0.0051^{\star}$ & $-0.0020^{\star}$ & $-0.0180^{\star}$ \\
\hline Age 4 & $0.1395^{\star}$ & $-0.0565^{\star}$ & $-0.0374^{\star}$ & $-0.0069^{*}$ & $-0.0080^{*}$ & $-0.0031^{\star}$ & $-0.0276^{*}$ \\
\hline Age 5 & $0.1930^{*}$ & $-0.0840^{*}$ & $-0.0513^{\star}$ & $-0.0091^{\star}$ & $-0.0104^{\star}$ & $-0.0040^{*}$ & $-0.0341^{*}$ \\
\hline Married & -0.0056 & 0.0020 & 0.0015 & 0.0003 & 0.0003 & 0.0001 & 0.0013 \\
\hline Inter-religion marriage & $-0.0746^{\star}$ & $0.0246^{\star}$ & $0.0200^{\star}$ & $0.0040^{\star}$ & $0.0048^{\star}$ & 0.0019 & $0.0193^{*}$ \\
\hline Income 1 & 0.0074 & -0.0027 & -0.0020 & -0.0004 & -0.0005 & -0.0002 & -0.0017 \\
\hline Income 2 & -0.0085 & 0.0031 & 0.0023 & 0.0004 & 0.0005 & 0.0002 & 0.0020 \\
\hline Income 3 & -0.0108 & 0.0039 & 0.0029 & 0.0006 & 0.0007 & 0.0003 & 0.0025 \\
\hline Illiterate & -0.1058 & 0.0330 & 0.0281 & 0.0058 & 0.0070 & 0.0028 & 0.0292 \\
\hline Elementary School & -0.0080 & 0.0029 & 0.0021 & 0.0004 & 0.0005 & 0.0002 & 0.0018 \\
\hline High school & 0.0240 & -0.0087 & -0.0065 & -0.0013 & -0.0015 & -0.0006 & -0.0055 \\
\hline PEA & -0.0171 & 0.0063 & 0.0046 & 0.0009 & 0.0010 & 0.0004 & 0.0039 \\
\hline Metropolitan & $-0.0375^{\star}$ & $0.0134^{\star}$ & $0.0101^{*}$ & $0.0020^{\star}$ & $0.0023^{*}$ & 0.0009 & $0.0088^{*}$ \\
\hline South & -0.0674 & $0.0227^{\star}$ & 0.0181 & 0.0036 & 0.0043 & 0.0017 & 0.0170 \\
\hline Northeast & -0.0138 & 0.0050 & 0.0037 & 0.0007 & 0.0009 & 0.0003 & 0.0032 \\
\hline Southeast & 0.0107 & -0.0039 & -0.0029 & -0.0006 & -0.0007 & -0.0003 & -0.0025 \\
\hline Homosexual Marriage & -0.0143 & 0.0052 & 0.0039 & 0.0007 & 0.0009 & 0.0003 & 0.0033 \\
\hline Adoption & -0.0133 & 0.0048 & 0.0036 & 0.0007 & 0.0008 & 0.0003 & 0.0031 \\
\hline Abortion & $0.0572^{*}$ & $-0.0199^{\star}$ & $-0.0154^{\star}$ & $-0.0030^{\star}$ & $-0.0036^{\star}$ & $-0.0014^{\star}$ & $-0.0139 *$ \\
\hline Religious institution & 0.0261 & -0.0097 & -0.0070 & -0.0014 & -0.0016 & -0.0006 & -0.0058 \\
\hline Prior Catholic & 0.0226 & -0.0080 & -0.0061 & -0.0012 & -0.0014 & -0.0006 & -0.0053 \\
\hline Prior Evangelical Pentecostal & 0.0229 & -0.0085 & -0.0062 & -0.0012 & -0.0014 & -0.0005 & -0.0051 \\
\hline Prior Evangelical non-Pentecostal & -0.0159 & 0.0056 & 0.0043 & 0.0008 & 0.0010 & 0.0004 & 0.0038 \\
\hline No prior religion & -0.0825 & 0.0268 & 0.0220 & 0.0045 & 0.0054 & 0.0021 & 0.0217 \\
\hline Catholic & -0.0088 & 0.0032 & 0.0024 & 0.0005 & 0.0005 & 0.0002 & 0.0020 \\
\hline Evangelical Pentecostal & $0.0928^{*}$ & $-0.0363^{*}$ & $-0.0250^{\star}$ & $-0.0047^{\star}$ & $-0.0054^{\star}$ & $-0.0021^{\star}$ & $-0.0192^{*}$ \\
\hline Evangelical non-Pentecostal & 0.0880 & -0.0354 & -0.0237 & -0.0044 & -0.0051 & -0.0020 & $-0.0175^{*}$ \\
\hline No religion & $-0.3603^{*}$ & $0.0695^{\star}$ & $0.0860^{*}$ & $0.0204^{*}$ & $0.0260^{\star}$ & $0.0109^{*}$ & $0.1475^{\star}$ \\
\hline
\end{tabular}

Source: Brazil Religion Survey (2007).

* Denotes statistical significance at the $5 \%$ level (p-value $<0.05$ ).

\section{Discussion}

Firstly, the strength of gender as an explanatory variable for the three models is remarkable - males are less religious than females, a finding vastly documented in the literature (VAUS; MCALLISTER, 1987; IANNACCONE, 1998; HALMAN; DRAULANS, 2006; OLIVEIRA; CORTES; NETO, 2013).

Concerning the age of respondents, it is noticeable that, as people grow older, they tend to show higher levels of disbelief but also higher church attendance. In their analyses 
of the British people, Voas and Crockett (2005) also found higher levels of disbelief than of religious active belonging. This suggests a passive belonging, or perhaps the existence of other reasons for religious participation, such as seeing the churches as places for social interaction.

Being married to someone from another religion did not have a significant effect on affiliation or belief, but it did affect religious practice. People in heterogamic marriage face a trade-off between their own religious practice and that of their spouse. Even if the spouse has no religion, there will be situations where they will need to choose between a secular activity and a religious one, for instance. Therefore, in summary, these people may not abandon their original beliefs, but their observance is likely to decrease.

With regard to the geographical aspects, Northeast inhabitants proved less prone to disaffiliate, an expected result given that the region is mostly Catholic. Jacob (2003) presented maps where the Northeast region appeared less influenced by the religious changes taking place in the country. In his words, the explanation is that

[...] this area of resistance of Catholicism frequently includes sparsely populated spaces, especially in the backlands, where there is strong social and political control, old and effective, by traditional oligarchies. [...] one must also consider the weight of religiosity, popular beliefs, oral tradition and the lesser influence of the media on change of attitudes of its population. In addition, the offer of other religions in the Northeast is smaller than in other areas of the country, since the effort required for the conversion of its inhabitants would be much larger, both in relation to the large areas involved and to the barriers imposed by the existing social and political control mechanisms. (JACOB, 2003, p. 127)

Moreover, the variable of comparison for regions was the North/Midwest, an area where Evangelicals are predominant in relation to the remaining regions. (Jacob, 2003). This may explain why Southeast, Northeast and South had a tendency to lower odds for religious practice when compared to North/Midwest.

Being in favor of homosexual marriage only affected the church attendance by reducing it. This is a sign of secularism because not only does it confirm the hypothesis that these people may feel uncomfortable in a religious environment (BRAÑAS-GARZA; GARCÍA-MUÑOZ; NEUMAN, 2008), but also it shows that they believe in some religious dogmas and not in others. The same explanation applies to the attribute of being in favor of adoption of children by homosexual couples, which had a significant effect on beliefs, reducing the odds to belief that some people go to Hell after death.

It is noticeable that the fact of studying or having studied in religious institutions did not show any relation to secularism (abandonment of religion, disbelief and lack of religious practice). Perhaps the effect was not significant because some schools exempt students from religious classes.

The most important factor to explain religiousness was clearly the current religion, but this result needs to be considered with caution. The definition of high religious activity and accepted religious dogmas varies from religion to religion. In 2007, nearly $83 \%$ Brazilian 
people were Christians (Catholic or Evangelical). For these religions, church attendance, prayer and beliefs about the existence of God, Heaven and Hell are expected. The same pattern may not be observed for other religions. Besides, the previous religion did not had any significant effect on beliefs or practice, but this may be due to the data format that considered previous religion in a general way and did not specify the religion in which the respondent was raised.

\section{Conclusions}

This paper researched if religion is losing relevance in Brazil. To that end, data from the Brazil Religion Survey (2007) was used, as well as concepts of the secularization theory and the theoretical framework of Azzi and Ehrenberg (1975) to model apostasy and lack of religiosity of Brazilian people. To affirm the existence of secularization, the hypotheses constituting the secularization theory that were presented in the literature review should be confirmed. Moreover, it was necessary to avoid seeing a full alignment between religious affiliation, practice and beliefs.

From the results, it is clear that the current religious affiliation had an impact on all manifestations of secularism - in general, having no religion decreased greatly the likelihood of having a religious practice and increased the likelihood of not believing that God exists. Being Evangelical decreased the propensity to disbelief and increased the chances of prayer, whereas being Catholic decreased the odds of leaving the church.

Males appeared more likely to lack religious practices and more prone to abandonment of religion. The fact of having a spouse with different religion was related to the absence of religious practice, but not with disbelief or disaffiliation.

As for the socio-economic attributes, it is worth noting that lower levels of household income had a negative impact on the probability of disaffiliation and disbelief. Meanwhile, the fact of being working or seeking employment was associated with increased likelihood of disbelief and lack of religious practices.

It was also observed that living in metropolitan areas was associated with lower levels of religiosity. Regarding macro-regions, although the Northeast was the most attached to religion, in terms of belonging to a religious institution, it did not imply that the northeastern were religious.

In summary, many results appeared as expected. But the socioeconomic characteristics, which are the most prominent in the secularism theory, did not have significance in virtually any model, and in some, appeared with a sign opposite to what was predicted. Another surprising outcome was the favorable opinion with regard to abortion laws that increased religiosity; this had no parallel with the literature and needs further research.

One limitation to disentangle the relationship between religion and income was the database that provided the income in the moment of data collection and not the income that the respondent had at the time of deciding to leave religion. To see how income affects 
beliefs and practices, each religious group should be separated by income - a suggestion for future work.

A way to clarify the impact of education would be to see the marginal effect of one more year of education in religious behavior, or the level of education at the time of religion abandonment. This analysis is not possible with the BRS database. It would be useful to consider the changes in religion and religiosity through time and relate them to the attributes of individuals at the time of change. This is another point that deserves further research.

With regard to the lack of correspondence among beliefs, religious activity and affiliation, one may argue how this itself can prove a sign of secularization. One may point out that people have their own set of beliefs, and that it may imply a religious revival instead of the decline of religion. In the present paper, the descriptive statistics showed that Brazil had very few atheists and that people tend to show high church attendance and prayer, and the proportions of those belonging to a religion and believing in some dogmas are high as well.

The response is simple: religion in general, and Christian religions in particular, tell people that they should believe in some statements and accept them as true; that they should go to church at least a given amount of time; and that commitment to the church is important. If there are people declaring attachment to a religion but with no religious practice, this actually points to disbelief in the doctrines. A belief in Heaven or Hell not followed by some practice or affiliation actually suggests that people do not believe in the necessity of these things or at least think that these are not connected to those beliefs, a contradiction to what is preached by religious institutions. ${ }^{4}$

In other words, they are deciding for themselves what to believe, not following the religious institution. Secularization means a loss of importance of religion, not a direct loss of importance of spirituality or God. Now, considering both the descriptive and econometric analyses, the results of this paper showed this discrepancy among beliefs, belonging and practices.

Therefore, the goal of providing information on the importance of secularism in order to explain the changes in Brazil's religious profile was reached - secularization exists in Brazil, but the processes that influence it need to be researched further to better understand the religious movements taking place in the country.

\section{References}

ALMEIDA, R. de; MONTERO, P. Trânsito religioso no Brasil. São Paulo em Perspectiva, v. 15, n. 3, p. 92-100, 2001.

ALVES, J. E. D.; CAVENAGHI, S. M.; BARROS, L. F. W.; CARVALHO, A. A. de. Distribuição espacial da transição religiosa no Brasil. Tempo Social, v. 29, n. 2, p. 215-242, 2017.

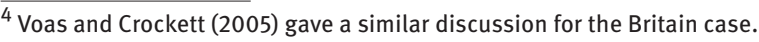


AZZI, C.; EHRENBERG, R. Household allocation of time and church attendance. Journal of Political Economy, v. 83, n. 1, p. 27-56, 1975.

BARRO, R.; MCCLEARY, R. M. International determinants of religiosity. Cambridge: National Bureau of Economic Research, 2003. (NBER Working Paper, 10147).

BRAÑAS-GARZA, P.; GARCÍA-MUÑOZ, T.; NEUMAN, S. Unravelling secularization: an international study. Bonn, Germany: Institute for the Study of Labor (IZA), 2007. (IZA Discussion Paper, 3251).

COSTA, F. J. M. D.; MARCANTONIO JUNIOR, A.; CASTRO, R. R. D. Stop suffering! Economic downturns and pentecostal upsurge. Rio de Janeiro: Escola de Pós-Graduação em Economia da FGV, 2018. (Ensaios Econômicos, n. 804).

COUTINHO, R. Z.; GOLGHER, A. B. The changing landscape of religious affiliation in Brazil 19802010: age, period and cohort perspectives. Revista Brasileira de Estudos de População, v. 31, n. 1, p. 73-98, 2014.

DOBBELAERE, K. Towards an integrated perspective of the processes related to the descriptive concept of secularization. Sociology of Religion, v. 60, n. 3, p. 229-247, 1999.

FONSECA, A. B. Nova Era evangélica: confissão positiva e o crescimento dos sem religião. Revista de Estudos e Pesquisa da Religião, v. 3, n. 2, p. 63-90, 2000.

GREENE, W. H. Econometrics analysis. 5. ed. Upper Saddle River, NJ: Prentice Hall, 2003.

HALMAN, L.; DRAULANS, V. How secular is Europe? The British Journal of Sociology, v. 57, n. 2, p. 263-288, 2006.

HACKETT, C.; GRIM, B. J. The global religious landscape: a report on the size and distribution of the world's major religious groups as of 2010. Pew Research Center, Pew Forum on Religion \& Public Life, 2012.

IANNACCONE, L. R. Introduction to the economics of religion. Journal of Economic Literature, V. 36, n. 3, p. 1465-1495, 1998.

INSTITUTO DE PESQUISAS DATAFOLHA. Brazil Religion Survey. 2007. Available in: 〈http://www. thearda.com/Archive/Files/Downloads/BRAZIL_DL.asp〉. Access in: Feb. 2015.

IRFFI, G.; CRUZ, M. S. da; CARVALHO, E. B. S. Reasons for embracing a religion: the case of Brazilian women. EconomiA, v. 18, n. 2, p. 168-179, 2017.

JACOB, C. R. Atlas da filiação religiosa e indicadores sociais no Brasil. São Paulo: Edições Loyola, v. 7, 2003.

MACHADO, M. D. D. C.; BURITY, J. A ascensão política dos pentecostais no Brasil na avaliação de líderes religiosos. Dados - Revista de Ciências Sociais, v. 57, n. 3, p. 601-631, 2014.

MCCLEARY, R. M.; BARRO, R. J. Religion and economy. Journal of Economic Perspectives, v. 20, n. 2, p. 49-72, 2006.

MONTERO, P. Secularização e espaço público: a reinvenção do pluralismo religioso no Brasil. Etnográfica - Revista do Centro em Rede de Investigação em Antropologia, v. 13, n. 1, p. 7-16, 2009.

MOREIRA-ALMEIDA, A.; PINSKY, I.; ZALESKI, M.; LARANJEIRA, R. Envolvimento religioso e fatores sociodemográficos: resultados de um levantamento nacional no Brasil. Revista de Psiquiatria Clínica, v. 37, n. 1, p. 12-15, 2010.

NERI, M. C. Economia das religiões: mudanças recentes. Fundação Getúlio Vargas, 2007.

OLIVEIRA, L. L. S. de; CORTES, R. X.; NETO, G. B. Quem vai à igreja? Um teste de regressão logística ordenada do modelo de Azzi-Ehrenberg para o Brasil. Estudos Econômicos, v. 43, n. 2, p. 363-396, 2013. 
PRANDI, R.; SANTOS, R. W. dos. Quem tem medo da bancada evangélica? Posições sobre moralidade e política no eleitorado brasileiro, no Congresso Nacional e na Frente Parlamentar Evangélica. Tempo Social, v. 29, n. 2, p. 187-213, 2017.

RODRIGUES, D. S. dos. Religiosos sem igreja: um mergulho na categoria censitária dos sem religião. Revista de Estudos da Religião, p. 31-56, dez. 2007.

STARK, R. Secularization, rip. Sociology of Religion, v. 60, n. 3, p. 249-273, 1999.

THE ASSOCIATION OF RELIGIOUS DATA ARCHIVES. Secularization. Pennsylvania: The Association of Religion Data Archives, 1998. Available in: 〈http://wiki.thearda.com/tcm/theories/ secularization/>. Access in: June 15, 2015.

VAUS, D.; MCALLISTER, I. Gender differences in religion: a test of the structural location theory. American Sociological Review, v. 52, n. 4, p. 472-481, Aug. 1987.

VOAS, D.; CROCKETT, A. Religion in Britain: neither believing nor belonging. Sociology, V. 39, n. 1, p. 11-28, 2005.

WILLIAMS, L. M.; LAWLER, M. G. Religious heterogamy and religiosity: a comparison of interchurch and same church individuals. Journal for the Scientific Study of Religion, v. 40, n. 3, p. 465-478, 2001.

\section{About the authors}

Caroline Carvalho is pursuing a master's degree in Economics at Graduate Program in Economics, Federal University of Ceará (Caen/UFC) and graduate in Economics from UFC.

Guilherme Irffi is Professor at Graduate Program in Economics, Federal University of Ceará (Caen/ UFC) and research fellow of Conselho Nacional de Desenvolvimento Científico e Tecnológico (CNPq).

\section{Contact address}

\section{Caroline Carvalho}

Graduate Program in Economics, Federal University of Ceará (Caen/UFC)

Avenida da Universidade, 2700, $2^{\circ}$ floor, Benfica

60.020-181 - Fortaleza-CE, Brazil

Guilherme Irffi

Graduate Program in Economics, Federal University of Ceará (Caen/UFC)

Avenida da Universidade, 2700, $2^{\circ}$ floor, Benfica

60.020-181 - Fortaleza-CE, Brazil

\section{Resumo}

Análise da secularização no Brasil

Este trabalho analisa se o Brasil está passando por um processo de secularização, utilizando dados da Pesquisa sobre Religião no Brasil, conduzida em 2007. Modelos de escolha discreta foram estimados para entender quais atributos dos indivíduos afetam a desfiliação, descrença e ausência de prática religiosa, para confirmar ou refutar as hipóteses do secularismo. A 
estimação confirmou algumas hipóteses da teoria. Por exemplo, ter uma opinião liberal acerca de assuntos morais e sociais está positivamente associado com secularismo, enquanto níveis mais baixos de renda incorrem em menores chances de desfiliação. Além disso, o perfil dos desfiliados, descrentes e não praticantes é semelhante. Portanto, é possível afirmar que existe secularização no Brasil.

Palavras-chave: Secularização. Brasil. Modelos de escolha discreta.

\section{Resumen}

\section{Análisis de la secularización en Brasil}

Este trabajo analiza si Brasil está pasando por un proceso de secularización, para lo cual utiliza datos de la Investigación sobre Religión en Brasil, desarrollada en 2007. Modelos de elección discreta fueron estimados para entender qué atributos de los individuos afectan la desafiliación, la incredulidad y la ausencia de prácticas religiosas, para confirmar o refutar las hipótesis del secularismo. La estimación confirmó algunas hipótesis de la teoría. Por ejemplo, tener una opinión liberal acerca de asuntos morales y sociales está positivamente asociado con el secularismo, mientras que ingresos más bajos implican menores posibilidades de desafiliación. Además, el perfil de los desafiliados, no creyentes y no practicantes es similar. Por lo tanto, es posible afirmar que existe secularización en Brasil.

Palabras clave: Secularización. Brasil. Modelos de elección discreta.

Received for publication in 30/04/2019

Approved for publication in 26/09/2019 